\title{
Rancang Bangun Sistem Jual Beli Banten Online
}

\author{
Ida Bagus Gede Jayeng Gotama, Ni Kadek Ayu Wirdiani, Ni Made Ika Marini Mandenni \\ Program Studi Teknologi Informasi, Fakultas Teknik, Universitas Udayana \\ Bukit Jimbaran, Bali, Indonesia, telp. (0361)701806 \\ e-mail:gotamajayeng@gmail,com,ayuwirdiani@unud.ac.id,made.ika.mm@gmail.com
}

\begin{abstract}
Abstrak
Banten merupakan sarana upacara dalam agama Hindu, yang pada umumnya dipersiapkan wanita Hindu di Bali. Keterbatasan waktu seiring perkembangan zaman modern saat ini, memunculkan kecenderungan masyarakat untuk membeli banten daripada membuatnya. Kecenderungan pembelian banten mendasari pengembangan sistem jual beli banten. Jual beli banten dirancang dilakukan secara online yang dikenal dengan E-Commerce, menggunakan metode pengembangan SDLC (System Development Life Cycle). Pihak penjual dapat menginputkan produk banten untuk memasarkan produknya, pada pihak pembeli juga dengan mudah memesan banten yang diinginkan hanya melalui aplikasi saja. Sistem memiliki otoritas admin yang dikembangkan dengan platform website, digunakan untuk memvalidasi pembeli, penjual dan barang penjual.
\end{abstract}

Kata Kunci : Banten, E-Commerce, SDLC, Website

\begin{abstract}
Banten is a ceremonial facility in Hinduism, which is generally prepared by Hindu women in Bali. Time constraints along with the development of modern times today, raises the tendency of people to buy banten rather than make it. The purchasing trend tends to underlie the development of the buying and selling system of banten. Buying and selling banten is designed to be done online, known as e-commerce, using the SDLC (System Development Life Cycle) development method. The seller can input Banten's products to market their products, the buyer can also easily order the desired cash only through the application. The system has admin authority developed with the website platform, used to validate buyers, sellers and seller items.
\end{abstract}

Keywords : Banten, E-Commerce, SDLC, Website

\section{Pendahuluan}

Bali terkenal dengan adat dan budaya Hindu yang kuat, upacara yadnya dilaksanakan secara rutin di Bali. Upacara yadnya mencakup berbagai aspek yang mendukung pelaksanaan ritual bagi komunitas Hindu di Bali [1]. Banten merupakan salah satu aspek pendukung dan sarana yang harus dipenuhi oleh Umat Hindu. Banten memiliki banyak jenis dan bentuk yang bermacam-macam. Pembuatannya banten menggunakan bahan dan sarana tertentu. Keterbatasan waktu seiring perkembangan zaman modern saat ini, memunculkan kecenderungan masyarakat untuk membeli banten daripada membuatnya. Kecenderungan pembelian banten mendasari pengembangan sistem jual beli banten. Jual beli banten dirancang dilakukan secara online yang dikenal dengan E-Commerce, menggunakan pengembangan metode SDLC.

Penelitian sebelumnya yang diacu diantaranya, sistem informasi membahas upacara Bayuh Oton terkait terkait upacara agama Hindu di Bali [2], game untuk pengenalan Tradisi Budaya di Bali terkait upacara agama Hindu di Bali dan aplikasi Android [3], serta sistem informasi manajemen bebantenan terkait bebantenan yang digunakan dalam upacara agama Hindu [4]. Penelitian mengenai sistem informasi upacara yadnya berbasis android membahas informasi terkait kegiatan upacara yadnya seperti waktu pelaksanaan, prosedur pelaksanaan, pemuput, tempat upacara, video, dan gambar upacara. Pengguna memperoleh data atau 
informasi dengan mengakses aplikasi dari sistem server. Penelitian mengenai sistem informasi terkait upacara Bayuh Oton membahas aplikasi yang digunakan untuk mempermudah mencari informasi terkait upacara tentang Bayuh Oton. Pemodelan sistem diagram tree digunakan untuk menghubungkan prosesi Bebayuhan Oton dengan banten dan sarana lain yang diperlukan. Penelitian mengenai media pengenalan Tradisi Budaya Bali dengan game berbasis Android yang dirancang untuk mengenalkan Tradisi Budaya Bali yang terdapat pada tujuh kabupaten/kota di Bali. Tradisi yang diperkenalkan pada game terdiri dari Ngerebong dari Denpasar, Mekotek dari Badung, Okokan dari Tabanan, Makepung dari Jembrana, Ngedeblag dari Gianyar, Megibung, Tektekan, Gebug Ende dari Karangasem, serta Ngocang, Bukakak tradisi budaya dari Buleleng. Tradisi budaya bali diimplementasikan berupa penjelasan dan gambar. Hasil penilaian mendapatkan peningkatan pengetahuan user mengenai Tradisi Budaya Bali bertambah sebanyak $74 \%$ dari persentase awal $67 \%$ melalui informasi yang ditampilkan. Penelitian tentang sistem manajemen informasi bebantenan membahas sistem manajeman data dari bebantenan yang mampu ditampilkan dalam website. Pemodelan sistem menggunakan diagram tree untuk menghubungkan bebantenan dengan perlengkapan yang diperlukan dan unsur bebantenan lainnya. Data bebantenan di-input-kan dalam sistem berupa teks, video dan gambar secara berurutan sesuai dengan kebutuhan sistem.

Pembaruan pada penelitian ini yaitu pemanfaatan implementasi E-Commerce untuk jual beli banten. E-Commerce dikembangkan menggunakan metode SDLC dengan perancangan melibatkan 2 jenis pengguna, yaitu penjual dan pembeli. E-Commerce saat ini merupakan suatu kebutuhan yang digunakan untuk meningkatkan persaingan bisnis [2]. Sistem dikembangkan dengan teknologi smartphone yang berkembang pesat saat ini yaitu smartphone berbasis Android [3]. Penjual banten yang ingin memasarkan produknya dirancang dapat melakukan input produk banten hanya melalui smartphone. Pihak pembeli juga dirancang dapat memesan melalui aplikasi saja dan dapat memperkirakan kapan pesanannya selesai.

\section{Metode Penelitian}

Metode pengembangan sistem menggunakan metode pengembangan SDLC atau disebut juga metode waterfall. Sistem jual beli banten online dikembangkan untuk platform android yang dapat berfungsi secara dinamis memberikan informasi banten, dimana dinamis dalam hal ini, berarti berbagai informasi banten pada aplikasi dapat ditambahkan atau dikurangi tanpa mengubah kode sumber aplikasi [5].

\subsection{Metode Pengembangan Sistem}

Metode System Development Life Cycle merupakan salah satu metode dalam pengerjaan setiap fase harus dikerjakan terlebih dahulu agar dapat melanjutkan ke fase berikutnya. Metode SDLC merupakan metode yang terdiri dari tahap perencanaan, analisis data, desain sistem, implementasi sistem, uji coba sistem dan pengelolaan sistem, dengan demikian hasilnya fokus terhadap masing-masing fase dilakukan secara maksimal. Kelebihan menggunakan metode waterfall diantaranya [6]:

1. Urutan pengerjaan setiap proses menjadi lebih teratur dari satu tahap ke tahap yang selanjutnya.

2. User dapat merencanakan sistem serta kebutuhan data dan proses yang diperlukan.

3. Jadwal pelaksanaan menjadi lebih teratur, sehingga target penyelesaian pengembangan sistem dapat terlihat jelas.

\subsection{ERD (Entity Relationship Diagram)}

Entity relationship diagram digunakan dalam penggambaran hubungan dari data serta pemodelan struktur data dari jual beli banten online. ERD dari sistem dapat dilihat seperti pada Gambar 1. 


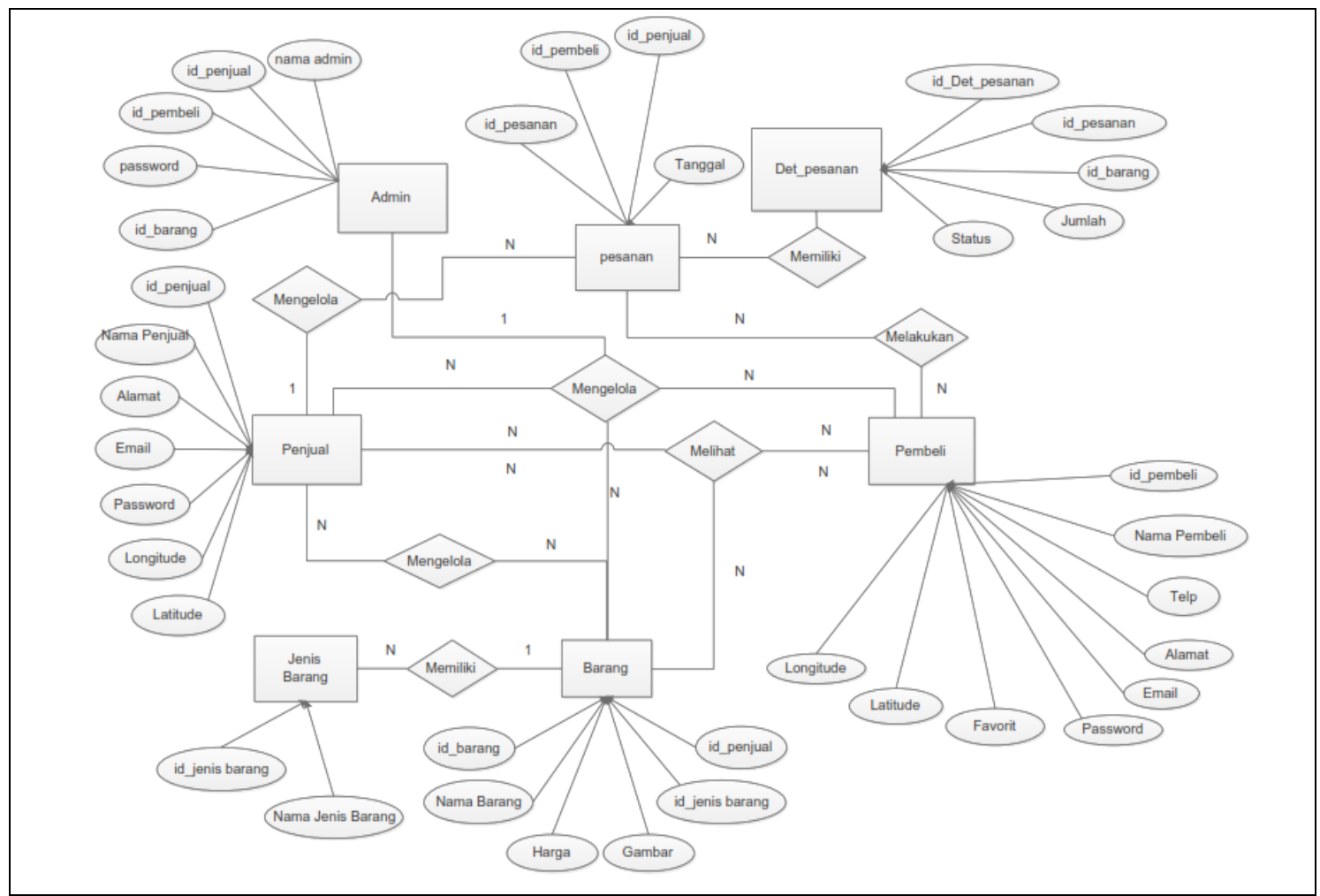

Gambar 1. Entity Relationship Diagram

Entitas admin memiliki relasi 1: $\mathrm{N}$ dengan penjual, pembeli dan barang. Entitas penjual memiliki relasi $\mathrm{N}: \mathrm{N}$ dengan entitas pembeli, relasi 1:N dengan entitas pesanan, dan relasi $\mathrm{N}: \mathrm{N}$ dengan entitas barang. Penjual memiliki relasi N:N dengan entitas pembeli, dan relasi N:N dengan entitas barang, dan relasi $\mathrm{N}: \mathrm{N}$ dengan entitas pesanan. Entitas jenis barang memiliki relasi $1: \mathrm{N}$ dengan entitas barang. Entitas detail pesanan memiliki relasi 1:N dengan entitas pesanan.

\section{Kajian Pustaka}

\subsection{Banten}

Banten merupakan suatu sarana penunjang pelaksanaan suatu upacara di Bali. Banten digunakan secara tersendiri maupun bersama banten lain memiliki fungsi dan maksud tersendiri terkait dengan upacara yang dilakukan. Banten memiliki banyak jenis dan bentuk yang bermacam-macam sehingga jika dilihat sepintas menimbulkan kesan unik dan rumit [4].

\subsection{E-Commerce}

E-Commerce dikenal dengan proses pertukaran informasi dan transaksi yang melibatkan barang dan jasa menggunakan teknologi informasi yang berkembang saat ini [7]. $E$ commerce dalam perkembangannya sudah menjadi media pemasaran atau promosi online yang sangat efektif dan secara spesifik dapat memperluas segmentasi pasar sasaran. Kemudahan melakukan transaksi dengan update informasi dengan biaya operasional yang lebih rendah membuatnya lebih praktis [8].

\section{Hasil dan Pembahasan}

Bagian hasil dan pembahasan menampilkan hasil tampilan dan membahas sistem jual beli banten yang telah dibuat. Tampilan sistem diantaranya, tampilan untuk pembeli, tampilan untuk penjual, serta tampilan untuk administrator. Sistem dibangun dalam aplikasi berbasis android. Aplikasi dapat dibuka dengan mudah melalui smartphone android. 


\subsubsection{Tampilan Sistem untuk Pembeli}

Tampilan sistem untuk pembeli merupakan tampilan aplikasi dari pengguna sistem sebagai pembeli banten. Tampilan aplikasi pembeli diantaranya, tampilan login dan register, tampilan dashboard menu beranda, dashboard jenis banten, beli banten, serta keranjang belanja. Pembeli dapat menggunakan fitur login jika sudah mempunyai akun dan fitur register dapat digunakan untuk mendaftarkan diri sebagai pembeli jika belum mempuyai akun. Tampilan login dan register pada aplikasi ditunjukkan pada Gambar 2.

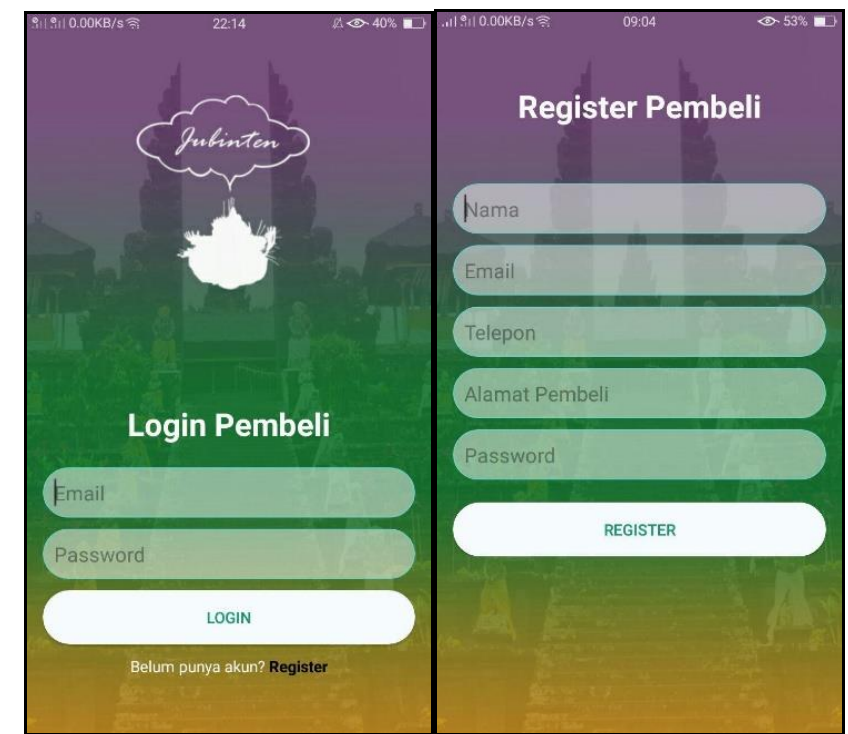

Gambar 2. Login dan Register Pembeli

Aplikasi jual beli banten online memiliki dashboard menu beranda dari pembeli yang telah melakukan login. Tampilan dashboard menu beranda dari pembeli, yang telah melakukan login pada sistem ditunjukkan pada Gambar 3.

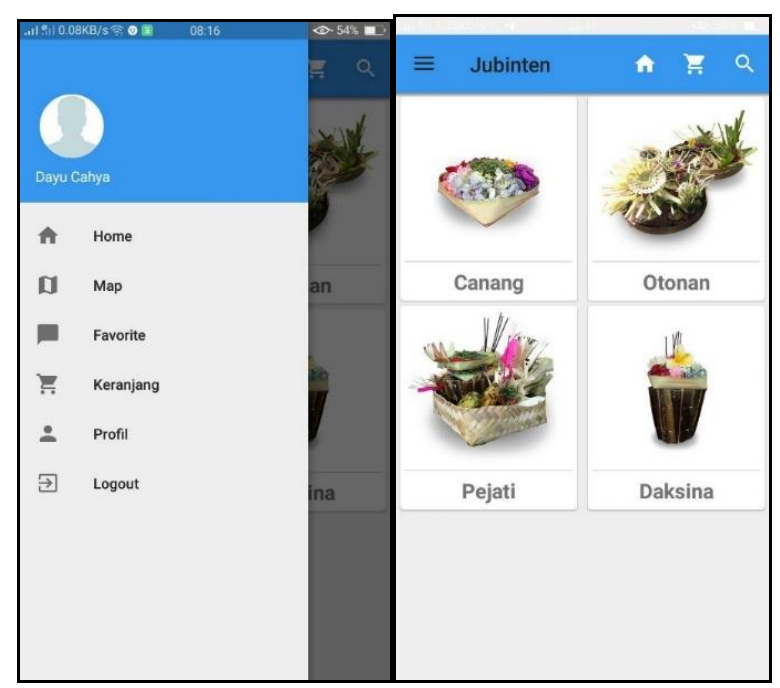

Gambar 3. Dashboard Menu Beranda

Aplikasi jual beli banten online memiliki dashboard jenis banten dari pembeli yang sudah melakukan login pada aplikasi. Tampilan dashboard jenis banten pembeli ditunjukkan pada Gambar 4. 


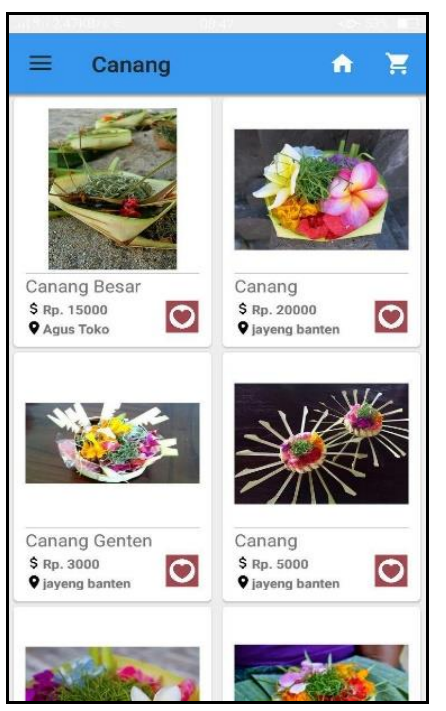

Gambar 4. Dashboard Jenis Banten

Pembeli pada aplikasi yang sudah melakukan login dapat membeli barang yang terdaftar di dashboard jenis banten. Tampilan beli banten yang dapat dilakukan oleh pembeli ditunjukkan pada Gambar 5.

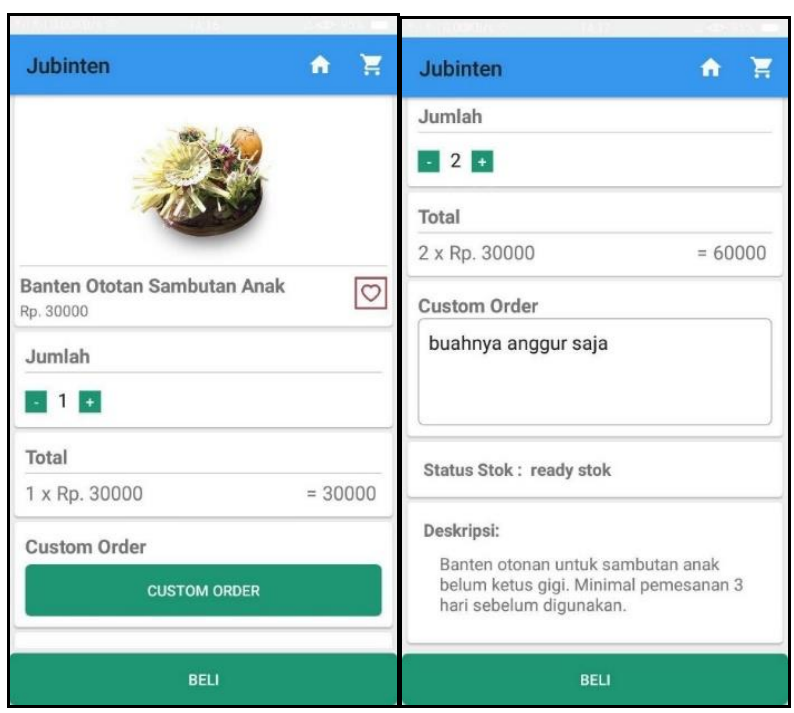

Gambar 5. Beli Banten

Pembeli banten yang sudah membeli banten mendapatkan tampilan barang pesanannya pada keranjang belanja. Tampilan keranjang belanja pembeli banten ditunjukkan pada Gambar 6 . 


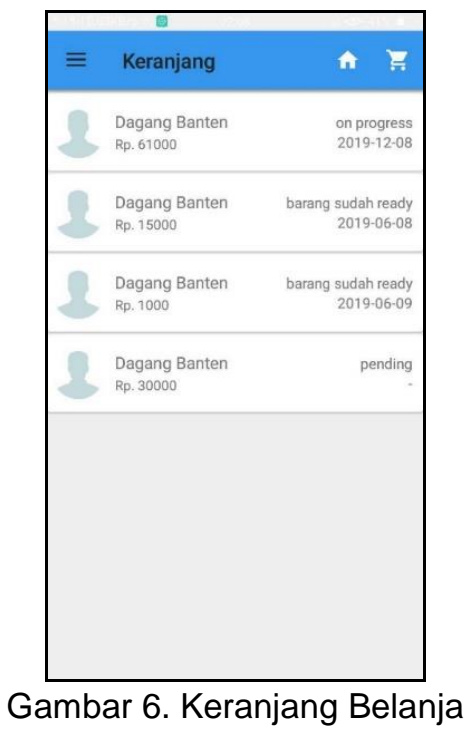

Keranjang belanja pembeli merupakan daftar banten yang telah dibeli pembeli yang berisi total harga dan nama penjual yang mempunyai barang bersangkutan. Pembeli yang sudah membeli barang, awalnya mendapatkan status pending yaitu pembeli masih harus menunggu konfirmasi dari penjual berapa hari diperlukan hingga barang siap diantarkan, status on progress yaitu barang sudah dikonfirmasi dan sudah mendapatkan hari atau tanggal barang siap diantarkan, dan status barang sudah ready yaitu barang yang diinginkan siap diantar kepada pembeli. Icon home dan keranjang belanja terdapat pada pojok kanan atas, yang memudahkan pembeli untuk melihat langsung dashboard utama ataupun keranjang belanja tanpa melakukan perintah kembali.

\subsubsection{Tampilan Sistem untuk Penjual}

Tampilan sistem untuk penjual merupakan tampilan aplikasi dari pengguna sistem sebagai penjual banten. Tampilan aplikasi penjual diantaranya, tampilan login dan register, tampilan menu beranda penjual, tampilan dashboard penjual, tampilan konfirmasi penjual kepada pembeli, serta tampilan input banten. Penjual dapat melakukan login menggunakan fitur login jika sudah mempunyai akun dan fitur register dapat digunakan untuk mendaftarkan diri sebagai penjual jika belum mempunyai akun. Tampilan login dan register pada aplikasi ditunjukkan pada Gambar 7.

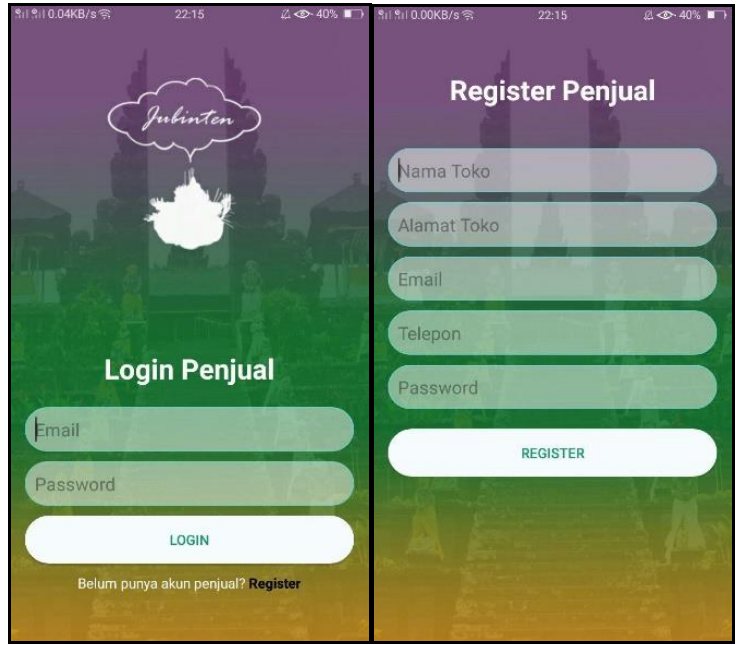




\section{Gambar 7. Login dan Register Pembeli}

Aplikasi jual beli banten online memiliki menu beranda untuk pengguna sebagai penjual yang telah melakukan login. Tampilan menu beranda dari pengguna sebagai penjual ditunjukkan pada Gambar 8.

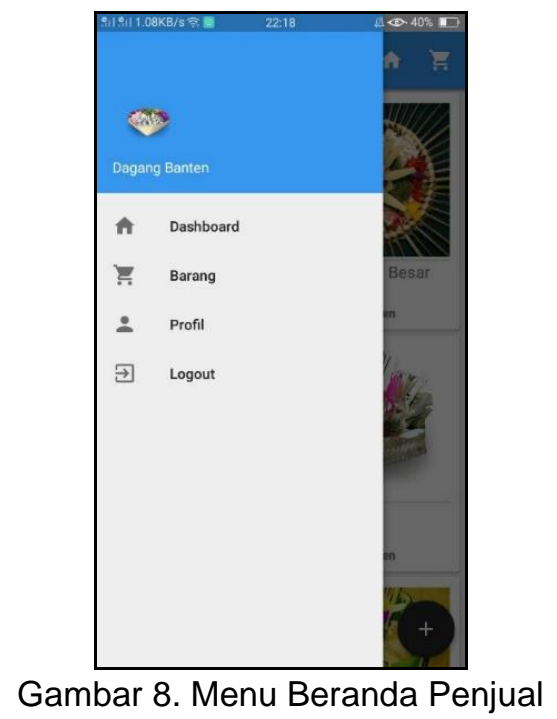

Aplikasi jual beli banten online memiliki dashboard penjual pada menu beranda penjual yang telah melakukan login yang berisi daftar pesanan dari pembeli. Tampilan dashboard pada menu beranda dari pengguna sebagai penjual yang telah melakukan login pengguna pada aplikasi ditunjukkan pada Gambar 9.

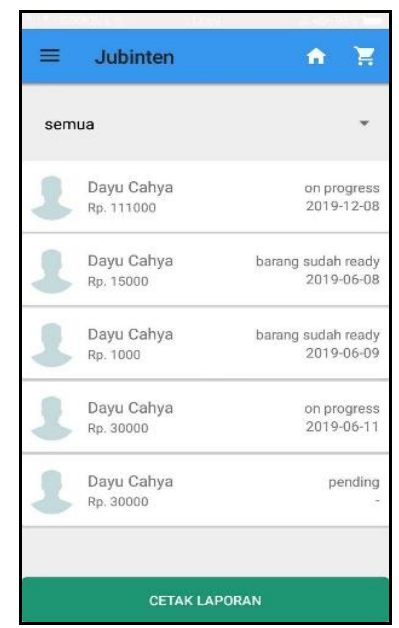

Gambar 9. Dashboard Penjual

Tampilan konfirmasi penjual kepada pembeli merupakan tampilan dari penjual yang melakukan konfirmasi jika barang banten sudah siap ataupun akan diproses. Tampilan konfirmasi dilakukan oleh penjual banten kepada pembeli ditunjukkan pada gambar 10. 


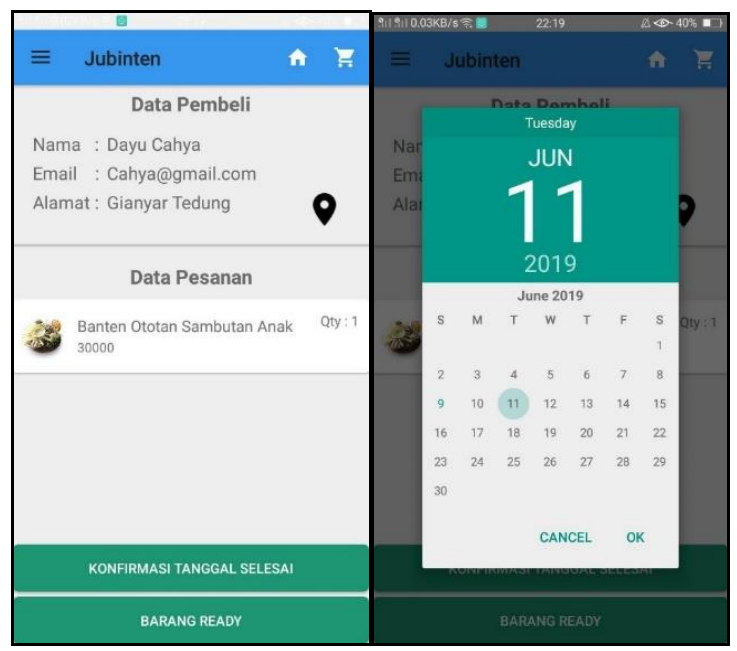

Gambar 10. Konfirmasi Penjual kepada Pembeli

Aplikasi jual beli banten online memiliki halaman input banten untuk penjual memasarkan produknya pada aplikasi. Tampilan input banten dari pengguna sebagai penjual ditunjukkan pada Gambar 11.

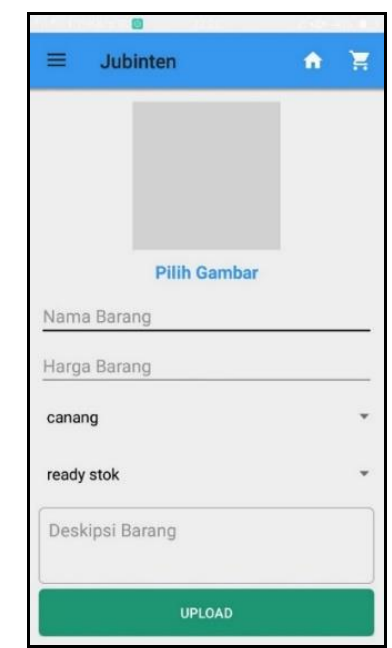

Gambar 11. Input Banten

Tampilan input banten menampilkan apa saja yang harus di-input-kan untuk memasarkan banten. Penjual harus input data seperti gambar banten, nama banten, jenis banten, status banten, serta deskripsi banten untuk memasarkan banten dengan semenarik mungkin.

\subsubsection{Tampilan Sistem untuk Administrator}

Tampilan sistem untuk administrator merupakan tampilan aplikasi dari pengguna sistem sebagai admin. Tampilan admin diantaranya, tampilan login, tampilan dashboard admin, tampilan validasi data penjual, tampilan validasi data pembeli, serta tampilan validasi data banten. Aplikasi jual beli banten online memiliki otoritas adminstrator yang dikembangkan dengan website. Berikut merupakan tampilan login administrator ditunjukkan pada Gambar 12. 


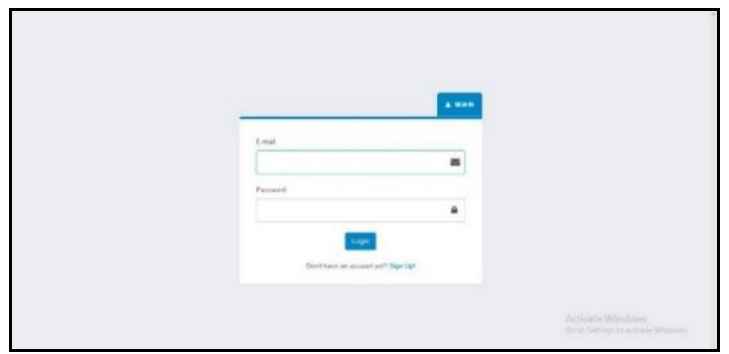

Gambar 12. Login Adminstrator

Aplikasi jual beli banten online memiliki otoritas adminstrator yang dikembangkan dengan website. Tampilan dashboard administrator yang sudah melakukan login pada website ditunjukkan pada Gambar 13.

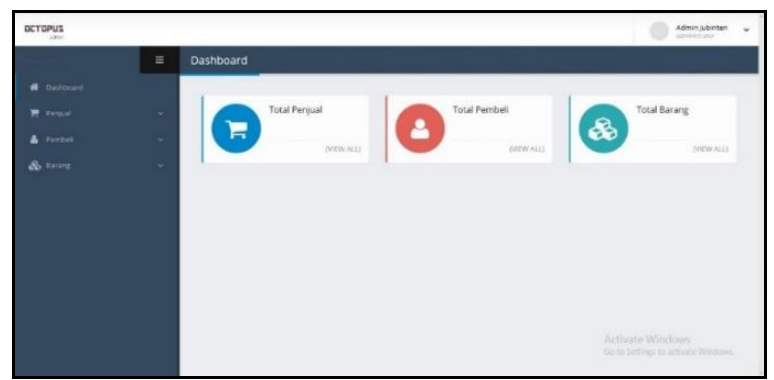

Gambar 13. Dashboard Admin

Aplikasi jual beli banten online memiliki otoritas administrator yang dikembangkan dengan website. Administrator mempunyai tugas untuk memvalidasi data penjual, data pembeli dan data banten. Administrator melakukan validasi dengan mengirimkan konfirmasi kepada akun pengguna aplikasi bahwa akun tesebut tidak dapat digunakan lagi, jika melakukan pengguna melakukan login. Data banten penjual yang tidak sesuai, dilakukan validasi dengan mengirimkan konfirmasi block banten pada barang yang dipasarkan penjual. Tampilan admin yang dapat melakukan validasi terhadap data penjual, data pembeli, serta data banten pada aplikasi ditunjukkan pada Gambar 14, Gambar 15, dan Gambar 16.

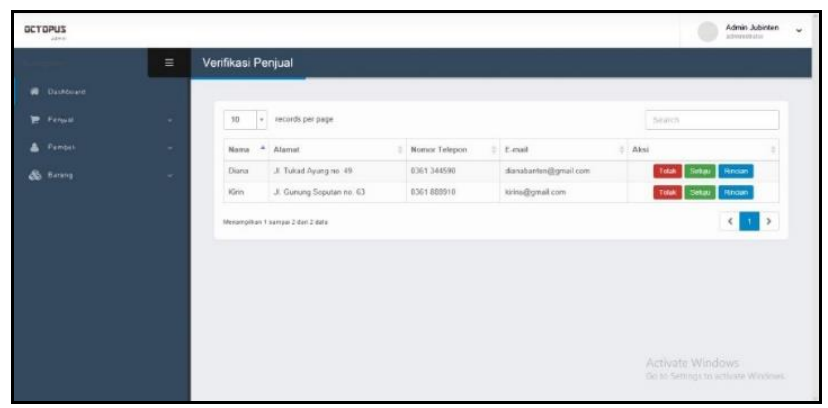

Gambar 14. Validasi Data Penjual 


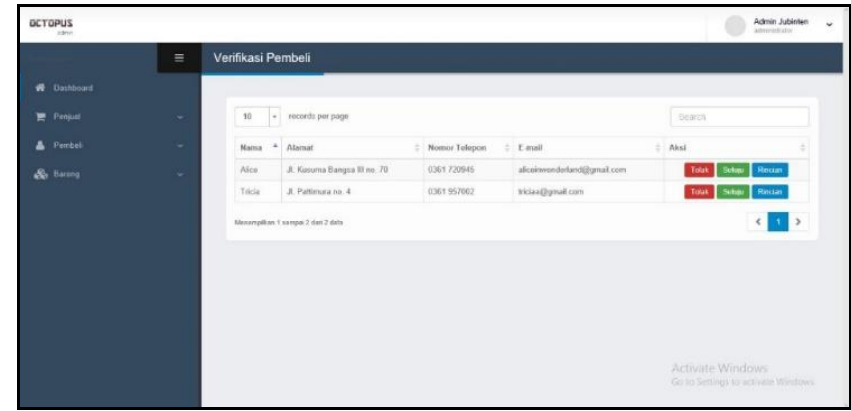

Gambar 15. Validasi Data Pembeli

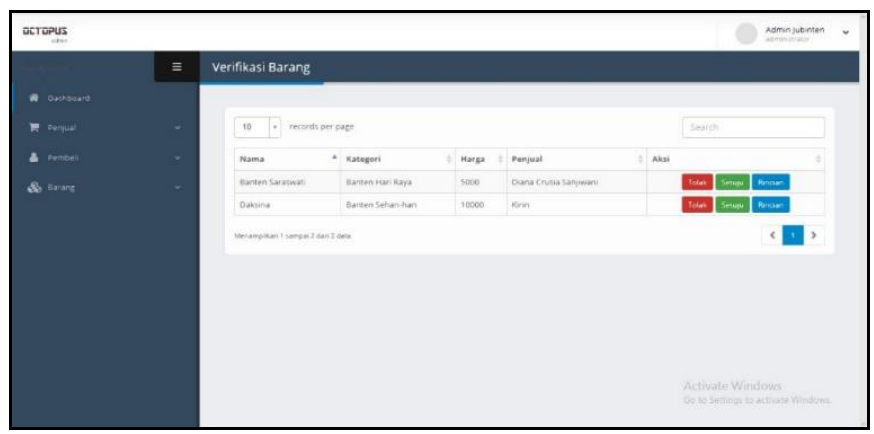

Gambar 16. Validasi Data Banten

\subsection{Analisis Sistem}

Analisis pada sistem diterapkan untuk mengetahui apakah aplikasi berfungsi dengan baik ataupun dapat diketahui jika terdapat masalah. Analisis dilakukan menggunakan smartphone yang berguna untuk mengatahui bagaimana aplikasi dapat digunakan pada beberapa kondisi ataupun spesifikasi smartphone yang berbeda. Analisis menghasilkan output berupa kelebihan dan kekurangan sistem. Kelebihan dan kekurangan aplikasi jual beli banten setelah dilakukan analisis sistem yaitu sebagai berikut.

Penerapan penjualan bebantenan dalam aplikasi jual beli banten memberikan beberapa kelebihan ataupun keuntungan bagi pengguna, kelebihan tersebut antara lain.

1. Rancang bangun jual beli banten online dapat diakses dengan mudah menggunakan berbagai smartphone android.

2. Rancang bangun jual beli banten online menampilkan tampilan yang dinamis dan mudah dimengerti atau friendly user.

Penerapan penjualan bebantenan dalam aplikasi jual beli banten mempunyai kekurangan bagi pengguna pengguna, kekurangan tersebut antara lain.

1. Rancang bangun jual beli banten online belum memiliki fitur negosiasi harga secara langsung antara penjual dan pembeli.

2. Rancang bangun jual beli banten online belum memiliki notifikasi secara realtime.

\section{Kesimpulan}

Hasil penilaian dari penyebaran kuesioner yang dilakukan kepada responden, yang terdiri dari 22 pertanyaan dibagi menjadi 4 kategori yaitu desain, warna, fungsionalitas dan kemudahan.

Hasil penilaian didominasi penilaian sangat setuju dan setuju. Kategori desain memperoleh $64 \%$ untuk penilaian sangat setuju dan $36 \%$ untuk penilaian setuju, kategori warna memperoleh $64 \%$ untuk penilaian sangat setuju, $28 \%$ untuk penilaian setuju dan $8 \%$ untuk penilaian cukup, kategori fungsionalitas memperoleh $90 \%$ untuk penilaian sangat setuju dan $10 \%$ untuk penilaian setuju, serta kategori kemudahan dalam menggunakan aplikasi memperoleh $72 \%$ untuk penilaian sangat setuju dan $28 \%$ untuk penilaian setuju. Rata-rata persentase tertinggi dari 4 
kategori pertanyaan yang diberikan yaitu pilihan sangat setuju, sehingga dapat disimpulkan bahwa aplikasi penjualan banten dapat mempermudah proses jual beli banten secara online.

\section{Daftar Pustaka}

[1] A. A. K. O. Sudana, I. M. Sukarsa, \& I. M. W. Saputra (2014). Information System of Yadnya Ceremony on Android-Based. International Journal of Hybrid Information Technology, 7(6), 155-164. https://doi.org/10.14257/ijhit.2014.7.6.13

[2] N. P. R. G. Dewi, O. Sudana, \& M. Sukarsa. (2017). Implementasi Diagram Tree pada Rancang Bangun Sistem Informasi Bebayuhan Oton Berbasis Web. Lontar Komputer : Jurnal IImiah Teknologi Informasi, 8(3), 178. https://doi.org/10.24843/lkjiti.2017.v08.i03.p04

[3] D. P. A. Sanjaya, I. K. A. Purnawan, \& N. K. D. Rusjayanthi. (2017). Pengenalan Tradisi Budaya Bali melalui Aplikasi Game Explore Bali Berbasis Android. Lontar Komputer : Jurnal IImiah Teknologi Informasi, 7(3), 162. https://doi.org/10.24843//kjiti.2016.v07.i03.p04

[4] N. K. R. Sadini, I. K. G. D. Putra, \& A. A. K. O. Sudana. (2014). Manajemen Data Sistem Informasi Bebantenan Bagian Banten/Upakara Berbasis Web. Jurnal Ilmiah Merpati Universitas Udayana, 2(3), 316-325.

[5] A. A. K. O. Sudana, A. Setiawan, \& I. P. A. E. Pratama. (2016). Augmented Reality for Chemical Elements : Journal of Theoretical and Applied Information Technology, 90(1), 8892.

[6] W. Nugraha, M. Syarif, \& W. S. Dharmawan. (2018). Penerapan Metode SDLC Waterfall dalam Sistem Informasi Inventori Barang Berbasis Desktop. Jurnal Sistem Informasi Musirawas (JUSIM), 3(1), 22. https://doi.org/10.32767/jusim.v3i1.246

[7] W. Febriantoro. (2018). Kajian dan Strategi Pendukung Perkembangan E-Commerce bagi UMKM di Indonesia. Manajerial, 3(5), 184-207.

[8] S. Kosasi. (2015). Perancangan Sistem E-Commerce untuk Memperluas Pasar. Snastia, 2015(Oktober), 110-119. 